\title{
NOW WHAT SHOULD WE DO WITH THEM?: ARTISTS' BOOKS IN THE CURRICULUM
}

Editor's note: This article is a revised version of a paper given at the Artists' Books Symposium, held at Connecticut College in New London, Conn., in the Spring of 2002.

TEACHING HAS BECOME A CENTRAL part of the job of nearly every academic librarian. Nowhere is this more true than in liberal arts colleges and other institutions where undergraduates are the primary focus. Whether or not librarians are able to offer courses for credit, we do a great deal of instruction at the reference desk, in group instruction sessions, and in one-on-one appointments. Although much of this teaching focuses on using online resources, a substantial portion is aimed at making sure that students understand that not everything is available on the Internet, nor will it ever be. We teach students how to locate and evaluate sources of all kinds, in all formats. Special collections librarians have a particular mission and responsibility to teach the history of the book; to look at books, manuscripts, and archives as artifacts; to expose students to ways of understanding primary sources that take into account more than just their texts.

Why is the book as artifact so important today, when ever-changing technology drives so much of our lives? The rise of electronic resources, of disembodied texts, makes the understanding of the book as both a text and an object with its own particular history of special importance. Many electronic texts (or paper reprints, for that matter) share a 
flat, historical quality that encourages the reader to consider them as timeless entities. For a full understanding and appreciation of the text, it is crucial to step back and look at more than just the text itself, to set it in its context. The physical book is indeed thriving, much to the surprise of many scholars and librarians who thought that the proliferation of electronic resources would sound the book's death knell.

Central to the mission of special collections departments in undergraduate institutions is the goal of encouraging students-and faculty-to make use of the rich resources we hold for a wide variety of disciplines and avenues of inquiry. Special collections can be intimidating, with the need for heightened security and careful handling to protect scarce, valuable, and fragile materials. Then there are the necessary restrictions on circulation outside the department, the prohibition against pens, the sign-in sheet, the required stowing away of personal possessions before entering the reading room. It is critical to demystify and revitalize special collections so that students will understand why it takes a little extra effort to use these materials and that the effort is well worth it. Librarians must dispel the idea that special collections is a museum of the book, where whispering is necessary and gloves are de rigueur. Without these extra efforts, special collections is at constant risk of being marginalized. When special collections becomes devalued, there is a ripple effect of compromise in the curriculum and in research at all levels.

Artists' books can be central to realizing the goal of promoting the importance of special collections to the undergraduate experience. Most artists' books invite the reader to touch, to interact with the book, to read it and figure it out. Many students find artists' books immediately captivating and more accessible than some of the traditional rare books in the collection. Artists' books can help make special collections less stuffy, which is all to the good. Some students are surprised to learn that not everything we collect is old or in Latin. Fine and private press books, particularly 
those with outstanding illustrations or nontraditional approaches to the text, also can help to draw students in to the collection. Of course, the lines between artists' books, fine press books, and private press books are often fuzzy, and I have not attempted to make clear, strict distinctions among them as they are used in the undergraduate curriculum.

How can artists' books be integrated into the teaching mission of the library? Artists' books offer an easy and valuable match of interests for art and art history students. A greater challenge that can be equally rewarding, however, lies in exposing students in other fields to these unfamiliar materials. This endeavor does not necessarily require an extensive collection of artists' books. Most liberal arts colleges have collections of artists' books, some vast, others just a few examples for teaching. Although resources in this area vary considerably, some success stories have emerged from Amherst College, the Claremont Colleges, Mills College, and Wesleyan University.

Artists' books that are somehow directly related to books of the past can be particularly useful in bridging the gap between historical collections and current work. At Wesleyan, in many survey presentations on the history of books and printing, I show both the 1493 Nuremberg Chronicle and Laura Davidson's Ideal City, which uses the image of the fall of Babylon from the Nuremberg Chronicle to stand for Boston during the Big Dig project. ${ }^{1,2}$ This kind of comparison helps students to understand the book artist's influences, while also rendering the early printed book more accessible. In the same vein, I show Lois Morrison's The Egg Queen, which is built around reproductions from a found nineteenth-century book with chromolithographs of eggs. ${ }^{3}$ By viewing The Egg Queen next to an egg book similar to the one that inspired the book artist, students begin to understand how very modern works are often direct outgrowths of historical works. 


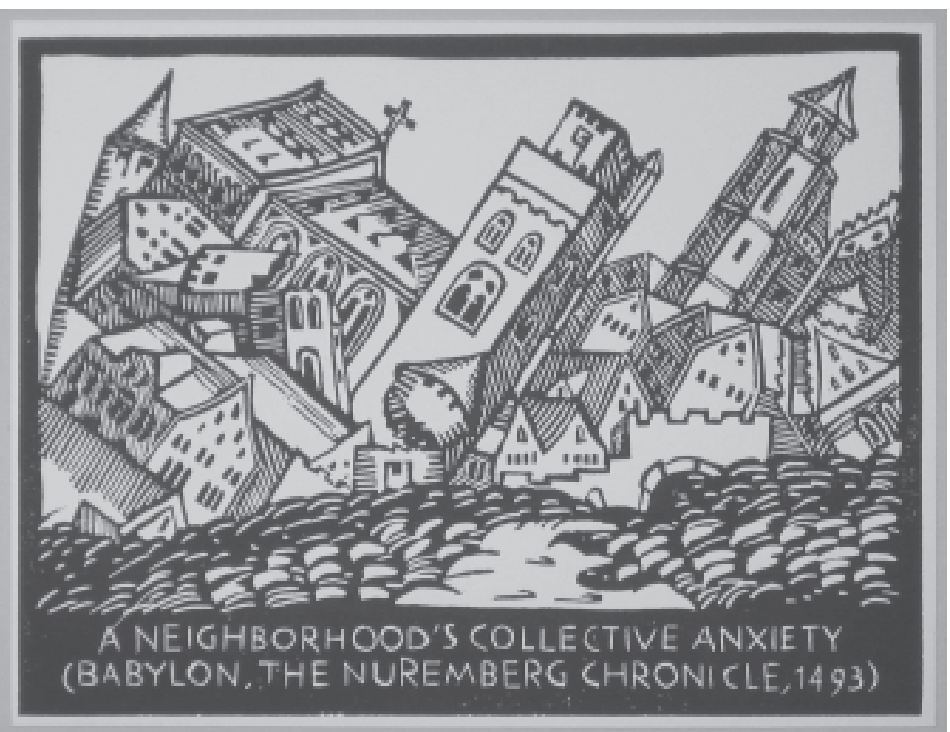

Laura Davidson. "A Neighborhood's Collective Anxiety (Babylon, The Nuremberg Chronicle, 1493)" in Ideal City. Boston: L. Davidson, 1997.

Through fine press and artists' books, students can gain a new appreciation for the current relevance of canonical literary texts and for the historical interpretations and reinterpretations of these texts. At the Claremont Colleges, Judy Harvey-Sahak, head of special collections, introduces Shakespeare students to Claire Van Vliet's illustrations for King Lear. ${ }^{4}$ At Scripps, one of the Claremont Colleges, students in a core curriculum class on images as textual interpretation select a text and compare its interpretation by three different illustrators. One of the most popular books for this assignment is Alice in Wonderland, and book artists' responses to this text play a key role. In Wesleyan's English Department, students reading Othello look at editions of the play from four centuries, including Leonard Baskin's Gehenna Press edition, with its dark, brooding illustrations. ${ }^{5}$ They contrast and compare these illustrations with earlier images of Othello, including the first illustrated

4. William Shakespeare, The Tragedies of King Lear, with woodcuts by Claire Van Vliet (Bangor, Me.: Theodore Press; Newark, Vt.: Janus Press, 1986).

5. William Shakespeare, Othello, illustrated by Leonard Baskin (Northampton, Mass.: Gehenna Press, 1973). 
edition published in $1709 .{ }^{6}$ Classes studying Cervantes, Chaucer, and Dante make similar comparisons among editions from different time periods.

Other classes follow their subject into contemporary, lesser-known texts found in artists' books. At Wesleyan, Shelly Rosenblum's American Studies class, House and Home in American Culture, viewed artists' books such as The Geography of Home, by Elizabeth Sanchez, Gene Holtan, and Gary Young, which uses an amazing array of illustration processes and home imagery. ${ }^{7}$ This class also looked at Marshall Weber's The House of Ghosts, which is printed on architectural plans found somewhere in the wilds of New Jersey. ${ }^{8}$ At Mills College, Janice Braun, special collections curator, worked with a seminar in German literature, showing artists' books, particularly the work of Unica $T$ and Thomas Gunther, as examples of special collections holdings for contemporary German studies. Music students at both Wesleyan and Claremont sometimes visit special collections with their classes. At Wesleyan, students in music librarian Alec McLane's section of Music 101 were introduced to Irene Woodbury and Barbara Valentino's Our Voice at the Brink of the New Millennium, which combines dance notation and music in unusual ways, and also to Robin Price's The Journey of the Guitar: A Portrait of Pepe Romero in His Own Words. ${ }^{9,10}$ At Claremont, music history students encountered Ron King's puppet book, Anansi Company, and students in a garden history course viewed Marylee Bytheriver's Beans and Lois Morrison's My Garden at Weeding Height. ${ }^{11-13}$ In Book Publishing: Theory and

6. William Shakespeare, The Works of Mr. William Shakespeare. In six volumes. Adorn'd with cuts. Revis'd and corrected, with an account of the life and writings of the author. By N. Rowe, Esq. (London: Printed for Jacob Tonson..., 1709).

7. Elizabeth Sanchez, Gary Young, and Gene Holtan, The Geography of Home: 40 Original Prints (Santa Cruz, Calif.: Quadqpress, 1987).

8. Marshall Weber, House of Ghosts (Brooklyn, N.Y.: Booklyn, 2000.

9. Irene Woodbury and Barbara Valentino, Our Voice at the Brink of the New Millennium (Bologna, Italy; Baltimore: Xpress, 2000).

10. Pepe Romero and Robin Price, The Journey of the Guitar: A Portrait of Pepe Romero in His Own Words, illustrated by James W. Pitts (Middletown, Conn.: Robin Price Publisher, 1999).

11. Ronald King and Roy Fisher, Anansi Company: A Collection of Thirteen Hand-made Wire and Card Rod-puppets Animated in Colour and Verse (London: Circle Press, 1992).

12. Marylee Bytheriver, Beans (Oakland, Calif.: Lunation Press, 1990).

13. Lois Morrison, My Garden from Weeding Height (n.p.: L. Morrison, 1993). 


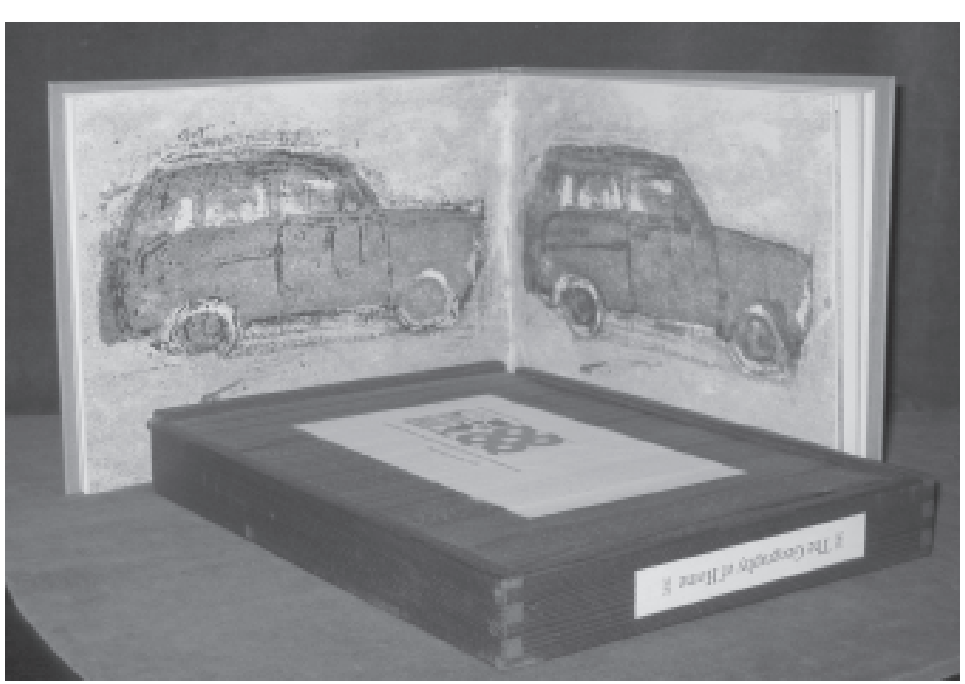

Edna Sanchez. "Squareback One" and "Squareback Two," with wooden case, in The Geography of Home. Santa Cruz: Greenhouse Review Press and Quadqpress, 1987.

Practice, taught by Tom Radko, Wesleyan University Press director, the first class is devoted to a "whirlwind tour" through the history of the book, beginning with cuneiform tablets and medieval manuscripts, and ending with Maria Pisano's Snake, a miniature book in the shape of a snake, every part of which is handmade by the artist. ${ }^{14}$ These encounters with noncanonical texts and illustrations in noncommercial editions introduce students to a world of contemporary art, writing, and publishing that is often completely new to them.

Artists' books often model new ways of presenting texts. At Amherst College, reference librarian Michael Kasper regularly presents artists' books to a Theater and Dance Department class called Scripts and Scores. The professor who teaches this course encourages students to present their creative projects in experimental ways, and she sees the artists' books as a great stimulant. At Mills, Janice Braun gave a presentation on "visual autobiography" to a visiting class from Berkeley. That class, which is crosslisted in English and visual studies, looked at a wide range of artists' books 
as expressions of autobiography. These students were exposed to texts they might not otherwise encounter, presented in creative and unusual formats.

In some cases, the structure of artists' books is the key focus for the curricular experience. At Harvey Mudd, one of the Claremont Colleges, Professor Jeffrey Groves teaches a humanities class called The Book in Western Culture to engineering and science students. The class divides into four groups, and each group chooses one of four books to study, write about, and eventually prepare a Web site. The science and engineering students particularly love Julie Chen's beautifully engineered book structures. At Mills, Janice Braun mounted an exhibit showcasing artists' books with unconventional structures. She related the structure to the content, rather than taking the more traditional approach of concentrating on technique, typography, theme, or illustrations.

Artists' books often force the reader to think about the very act of reading and how it is influenced by a variety of factors beyond the text itself. At Wesleyan, an assignment for a section of The Study of Literature, the English Department's introduction to literary analysis, offered an intensive focus on how a text is altered by the circumstances of its publication. Students in this course examined individual poems in collections of poetry broadsides. In looking at the broadsides, the students studied not only the texts of the poems, but also layout, paper, type, illustrations (when applicable), and relationships among the broadsides in the collection. These aspects of the poem in broadside format were contrasted with the look and feel of the same poem in the Norton Anthology of Poetry and the influence of the editorial voice that is so prevalent in the introductory biographical notes, ordering, and selection of the anthology. ${ }^{15}$ In an exhibition on teaching using special collections and archives, Stephanie Kuduk, the professor with whom I collaborated, wrote about the project: 
In essence, the assignment is geared toward exploring the literary dimensions of publishing venues that are more interesting and deliberate than the Norton Anthology, our standard text. These dimensions include relations among a series of poems, "paratext" prefaces and notes, illustrations, the poetic possibilities opened by the size and shape of posters and postcards, and the audiences implied by the material object of the poem. My hope is that the assignment leads students to open doors into new bodies of poetry, new writers, new means of publication, and especially into a renewed appreciation for poetry and poetics. In practice, the assignment proved enjoyable and felt adventuresome, and many students wrote their best essays of the term. ${ }^{16}$

Students in the class wrote eloquently about their readings of the poems in what, for most, was a new format. David Laub wrote about Elizabeth Jennings's poem, "The Child and the Seashell," which appears in the collection of broadsides, Poems in Folio ${ }^{17}$ :

In Jennings" own words, this poem was an attempt to "give a dynamic quality to a static event." The rhetoric of the poem certainly is instrumental in communicating this idea, but, in addition, as I considered this statement, I realized that so was the broadside format. This poem is all about making a special event out of a seemingly ordinary one, and the beautiful form of the broadside does the exact same thing to the poem itself. The broadside format thus makes this poem seem special and distinct in many ways, all of which enhance its meaning and effect on the reader. ${ }^{18}$

16. "Old Books, New Pedagogy: Special Collections and Archives in the Curriculum" was on view in Olin Library at Wesleyan University in the Spring of 2002. The exhibition is now available online at http://www.wesleyan.edu/libr/schome/exhibit/index.htm.

17. Poems in Folio 1 (1957).

18. David Laub, "Form Embodies Content." Class paper for English 201, "The Study of Literature," Stephanie Kuduk's section, Nov. 2000. The complete text of this, and other students papers, appears on the "Old Books, New Pedagogy" exhibition Web site. 
Another student, Ariana Mufson, selected a portfolio of broadsides called Concrete Poetry: Britain, Canada, United States. ${ }^{19}$ Writing about Emmett Williams's poem, "she loves," she concluded:

Broadsides allow the concrete poet to create visual imagery, which is inherent to this type of poetry. The typeface becomes incredibly important, as the words and lineation are just as descriptive as the actual forms that the letters create. Concrete poetry mimics artwork; a broadside could be hung on a wall, instead of a painting, with letters making up the images instead of actual figures or objects. This startling type of poetry requires a flexible medium. A poetry book would not be sufficient to portray the images of these concrete artists. ... Their work actualizes a vision of words as a universal language, where visual meaning is just as important as literal relevance. ${ }^{20}$

The poetry broadside assignment is a model for collaboration between a faculty member and a librarian, a model for actually using materials in special collections rather than simply viewing them in a museum-like setting. It also is a successful way to bring artists' books and fine press materials out of their natural habitat, the art program, and into the rest of the curriculum.

Other possibilities exist outside the traditional classroom setting. At Wesleyan in the Spring of 2003, student curator Beau Martin and I collaborated on an exhibition focusing on the book artist as social critic. The exhibition was one portion of a semester-long individual tutorial designed to examine different aspects of the history of the book. Because the display area at Wesleyan's Olin Library is in a central location through which large numbers of library researchers and visitors pass each day, we know that many students caught at least a glimpse of the exhibition. The

19. Stephen Bann and Jasia Reichardt, Concrete Poetry: Britain, Canada, United States, 13 Texts (n.p.: Edition Hansjorg Mayer, 1966).

20. Ariana Mufson, "Concrete Poetry: An Artistic Universal Language." Class paper for English 201, "The Study of Literature," Stephanie Kuduk's section, Nov. 2000. 
focus on the book arts and social critique was deliberately chosen to mesh with Wesleyan's high level of student activism and to attract students who might not otherwise have any contact with special collections.

Of course, the most obvious role of artists' books in the curriculum is to support studio arts and art history classes. Wesleyan offers book arts courses in both the undergraduate and graduate liberal studies curricula. The Graduate Liberal Studies Program, or GLSP, serves as both a continuing education program and a grantor of master's degrees in liberal studies. This program has a population of about three hundred adults, most of whom are employed full-time, many as teachers in Connecticut's public and private secondary and elementary schools.

Art classes in both undergraduate and graduate programs regularly visit special collections to view examples of artists' books. Keiji Shinohara's class in Japanese woodblock printing comes to see Western examples of relief printing. David Schorr's Introduction to Typography and Graphic Design is inspired by historical examples of fine typography and printing, as well as by artists' books, both letterpress and computer generated. Stephanie Wiles, curator of the Davison Art Center, brings various classes to special collections. Her History of Photography class views examples of photographically illustrated books, studying the history of this process and its relation to the text. The photographic books provide illuminating contrasts to the stand-alone art and documentary photographs that are the focus of the course. In her History of Prints course, students take a similar approach to the history of woodcuts, engravings, etchings, lithographs, and other printmaking techniques, as well as examining artists' books that use prints as illustration. In her Museum Studies class, students learn about connoisseurship in book collecting, from medieval manuscripts to artists' books.

In the GLSP, Kitty Winslow's class, Land Echoes: An Artist's Book, looked at photographs in artists' books before working on their own book projects, 
which were to include photographs of the Connecticut River. Sue Berry's class, Florilegia and Herbals: Artists' Books, studied both historical herbals and examples of many different kinds of artists' books, again with the purpose of informing their own creation of books. Robin Price's class viewed Mary McCarthy's Spirit of the Land, which uses boiled Polaroid photos as illustrations. ${ }^{21}$ This unusual technique inspired one of the students to cook and dissect some of her own Polaroid photos at home for use in her project.

Inspiring and nurturing new book artists is one of the best things a librarian can do with an artists' book collection. At Claremont, studio art students make books from found objects using fairly unsophisticated methods. The artists' book collection is a real inspiration for these students. As Judy Harvey-Sahak wrote to me: "Someone wise once said, 'Students are terrific because they don't know what they can't do.' The books they make may be somewhat crude from the standpoint of technical expertise, but conceptually they can be quite amazing." ${ }^{22}$

In fact, it was my initial encounters with student book artists that spurred me to expand Wesleyan's then tiny collection of artists' books. Soon after I arrived at Wesleyan in 1997, I was invited by Emily Larned, then an undergraduate and now a book artist whose work is held by the Library of Congress and several other collections, to a student-run artists' book tutorial to participate in a critique. Before this experience, my own knowledge of artists' books was mostly academic: although the large research libraries in which I worked did collect a few examples, I had no real evidence of their use by undergraduates. The tutorial was eye-opening. I began to see how artists' books could have an important role in the collection. The key to the matter lies in the curriculum, in making sure that the books are used in a variety of settings and by a range of students. Two of the seven or eight students in the artists' book tutorial, Emily herself and Anne Thompson, went on to create 
groups of artists' books for their senior theses, and I was asked to serve as an outside critic for both projects. Watching student book artists grow and seeing their work evolve is very exciting. As we build our artists' book collections in primarily undergraduate institutions, we must focus on what will speak to our students, in all disciplines, present and future, and on how these materials will support the curriculum. 